\title{
Development of Charging Technique for Controlling Mixed Coke Distribution in Ore Layer
}

\author{
Yusuke KASHIHARA, ${ }^{1{ }^{*}}$ Yasuyuki MORIKAWA, ${ }^{2)}$ Takeshi SATO, ${ }^{1)}$ Natsuo ISHIWATA ${ }^{1)}$ and Michitaka SATO ${ }^{3)}$ \\ 1) Steel Research Laboratory, JFE Steel Corporation, 1 Kawasaki-cho, Chuo-ku, Chiba, 260-0835 Japan. \\ 2) East Japan Works (Chiba), JFE Steel Corporation, 1 Kawasaki-cho, Chuo-ku, Chiba, 260-0835 Japan. \\ 3) Steel Research Laboratory, JFE Steel Corporation, 1-1 Minamiwatarida-cho, Kawasaki-ku, Kawasaki, $210-0855$ Japan.
}

(Received on August 21, 2014; accepted on November 10, 2014)

\begin{abstract}
A technique for controlling the mixed coke distribution in the ore layer was investigated in order to achieve low RAR operation of the blast furnace. A reduction test under load was performed with various mixed coke ratio distributions in the height direction. As a result, the ore reduction degree with a high mixed coke ratio in the upper part of the ore layer mixed with coke was higher than ore reduction degree with a uniform mixed coke ratio from the upper part to the lower part of the layer. The effect of the charging pattern on the mixed coke distribution in the ore layer mixed with coke was investigated by a scale model experiment. As a result, it was possible to form an ore layer with a high coke ratio in the upper part of the ore layer mixed with coke at the furnace top by controlling the burden shape of the mixed materials stacked in the top bunker. An operating test was carried out at JFE Steel's Chiba No. 6 blast furnace on the basis of the laboratory test results. Gas utilization improved after this technique was applied.
\end{abstract}

KEY WORDS: blast furnace; low RAR operation; coke mixed charging; burden distribution; bell-less charging; small coke.

\section{Introduction}

Reduction of $\mathrm{CO}_{2}$ emissions from the steel industry is an important environmental issue, and development of technologies for low carbon ironmaking is expected. In blast furnace operation, low RAR (Reducing Agent Rate) operation is desired in order to decrease $\mathrm{CO}_{2}$ emissions. ${ }^{1)}$ As improved permeability and decreased heat loss are important for achieving low RAR operation, the radial distribution of the ore-to-coke ratio was investigated from this viewpoint. ${ }^{2,3)}$ Coke and ore mixed charging has also been investigated. ${ }^{4-10)}$ Improved permeability in the cohesive zone and a higher ore reduction rate were achieved by applying appropriate charging techniques. Based on these results, charging techniques are expected to be effective for achieving low RAR operation and have already been applied to actual blast furnaces. ${ }^{6-8)}$

In past studies, improvement of the high temperature properties of the ore by mixing coke and ore was investigated. Although some of these studies investigated a uniform mixing condition of the coke in the ore layer, the effect of the mixed coke ratio distribution on ore reducibility was also investigated. Orimoto et al. ${ }^{11)}$ performed a reduction test at the same ore layer thickness as that in the actual blast furnace, and showed that the ore reduction degree was low in the upper part of the ore layer. Another test showed that the reduction degree in the low reduction degree zone

* Corresponding author: E-mail: y-kashihara@jfe-steel.co.jp

DOI: http://dx.doi.org/10.2355/isijinternational.55.1165 was increased by mixing nut coke around the ore with a low reduction degree, and in this case, the average reduction degree of the ore layer also increased. ${ }^{12)}$ However that study did not include experiments in connection with the high mixed coke ratio condition. Therefore, these reduction tests should also be performed for the high mixed coke ratio condition.

The relationship between the method of charging mixed coke into the blast furnace and the mixed coke ratio distribution in the ore layer at the furnace top after charging was also investigated. Murao et al. ${ }^{8)}$ performed an experiment to observe the cross section of an ore layer mixed with coke at the furnace top after charging, in which a low viscosity liquid resin was poured from the surface of the burden, and a sample was cut off after the resin solidified. The radial mixed coke ratio distribution in the ore layer mixed with coke was shown, and a charging technique for controlling the mixed coke uniformly was developed. Uchida et al. ${ }^{13)}$ performed a PIV analysis to observe the segregation phenomena of the mixed coke under the condition that a mixture of coke and ore was charged, and showed the effect of the segregation phenomena of the mixed coke on the mixed coke ratio distribution in the ore layer mixed with coke. However, investigation of the mixed coke distribution in the ore layer mixed with coke at the furnace top after charging is still insufficient. Especially, virtually no research has been done on the effect of the charging method on the mixed coke ratio distribution in the ore layer mixed with coke at the furnace top after charging. For application to actual blast furnaces, the relationship between the charging method and 
the mixed coke ratio distribution in the ore layer mixed with coke should be investigated.

In this study, a reduction test under load was performed to investigate the effect of the mixed coke ratio distribution in the ore layer mixed with coke on the reduction behavior of the ore under a the high mixed coke ratio condition. Next, a scale model experiment was performed to investigate a charging method for controlling the mixed coke ratio distribution in the ore layer mixed with coke. Finally, an operating test in which the charging method was changed was carried out at JFE Steel's East Japan Works (Chiba District) No. 6 blast furnace.

\section{Effect of Mixed Coke Ratio Distribution on Reduc- tion Behavior of Ore Layer Mixed with Coke}

\subsection{Experimental Procedure}

The effects of the mixed coke ratio distribution in the ore layer mixed with coke on the reduction behavior of the ore were investigated by a reduction test under load. A schematic illustration of the experimental apparatus is shown in Fig. 1. Sinter and coke were used in this test. The amount of sinter was $900 \mathrm{~g}$, and the sinter particle size was 10-15 $\mathrm{mm}$. The amount of coke was $69 \mathrm{~g}$, and the coke particle size was $10-15 \mathrm{~mm}$. The sinter and coke were divided into three portions as samples for the upper, middle and lower parts. The sinter and coke mixture was set into a carbon crucible $(100 \mathrm{~mm} \phi)$ so that the mixed coke was uniform

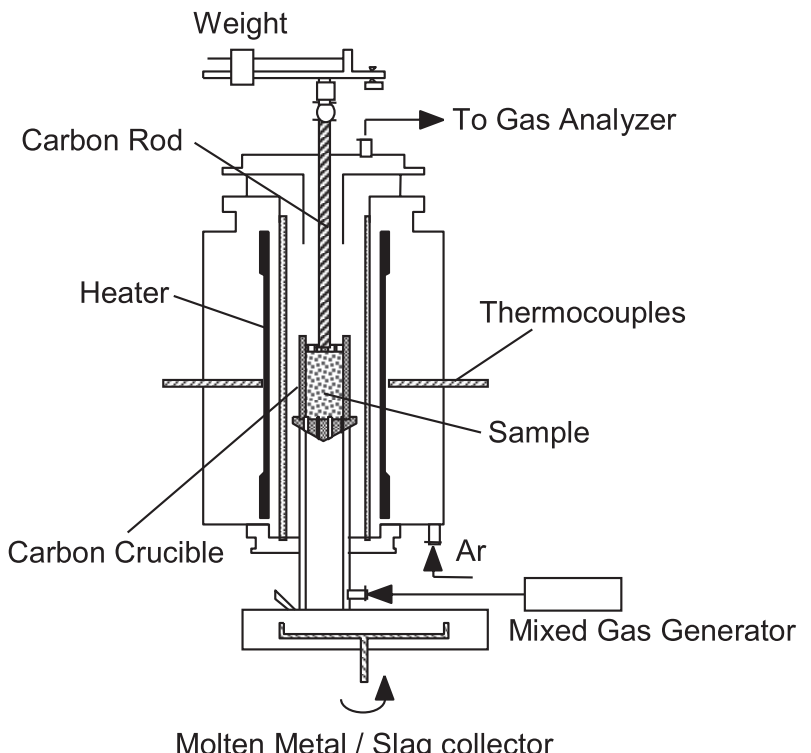

Fig. 1. Experimental apparatus for reduction test under load. in the each part (total layer thickness: $72 \mathrm{~mm}$ ). The mixing conditions of the mixed coke in the ore layer mixed with coke are shown in Fig. 2. In the Base case, the mixed coke is uniformly distributed. In Case 1, the distribution of the mixed coke in the upper part of the ore layer mixed with coke is high (layer thickness: $27 \mathrm{~mm}$ ), and the distribution of the mixed coke in the lower part is low (layer thickness: $21 \mathrm{~mm}$ ). Conversely, in Case 2, the distribution of the mixed coke in the lower part of the layer is high (layer thickness: $27 \mathrm{~mm}$ ), and that in the upper part is low (layer thickness: $21 \mathrm{~mm})$. The chemical compositions of the sinter and the coke are shown in Table $\mathbf{1 .}$

The crucible was set in an electric furnace, and a reduction was performed under conditions simulating the gas composition and temperature in an actual blast furnace. In this experiment, the gas composition and heating pattern were decided referring to measurements by the vertical probes at Chiba No. 1 and 2 blast furnaces. ${ }^{14)}$ The gas flow rate was $1.8 \mathrm{Nm}^{3} / \mathrm{h}$. The gas composition, heating pattern and load are shown in Fig. 3. After the temperature increased to a predetermined level, the mixed gas was changed to $\mathrm{N}_{2}$ gas and the sample in the furnace was cooled. The cooled sample was then taken out of the furnace, and a chemical analysis was carried out to examine reduction degree (RD). The RD of the sinter was calculated by the following Eq. (1).

$$
\mathrm{RD}=(\mathrm{O} 1-\mathrm{O} 2) / \mathrm{O} 1 \times 100
$$

where, $\mathrm{O} 1$ is the amount of oxygen for reduction in the sinter before the reduction test, and $\mathrm{O} 2$ is the residual amount of oxygen for reduction in the sinter after the reduction test.

\subsection{Experimental Results}

The effect of the mixed coke ratio distribution in the ore layer mixed with coke on the reduction degree at $1200^{\circ} \mathrm{C}$ is shown in Fig. 4. The reduction degree in the lower part of the ore layer mixed with coke is high compared with that in the upper part of the layer. The average reduction degree of the ore layer mixed with coke changed depending on the difference in the mixing condition of the coke in the ore layer.

Table 1. Chemical compositions of sinter and coke (mass\%).

\begin{tabular}{cccccccc}
\hline & $\mathrm{T}-\mathrm{Fe}$ & $\mathrm{FeO}$ & $\mathrm{CaO}$ & $\mathrm{SiO}_{2}$ & $\mathrm{Al}_{2} \mathrm{O}_{3}$ & $\mathrm{MgO}$ & $\mathrm{MnO}$ \\
\hline Sinter & 57.6 & 9.87 & 9.68 & 5.00 & 1.93 & 1.26 & 0.36 \\
\hline & Ash & V.M & F.C & $\mathrm{S}$ & $\mathrm{CaO}$ & $\mathrm{SiO}_{2}$ & $\mathrm{Al}_{2} \mathrm{O}_{3}$ \\
\hline Coke & 11.5 & 0.9 & 87.6 & 0.47 & 0.25 & 6.35 & 3.04 \\
\hline
\end{tabular}

Mixed coke ratio $(\%)$

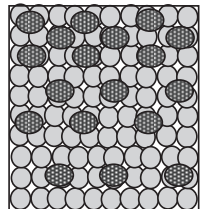

Case1

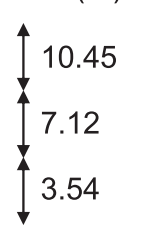

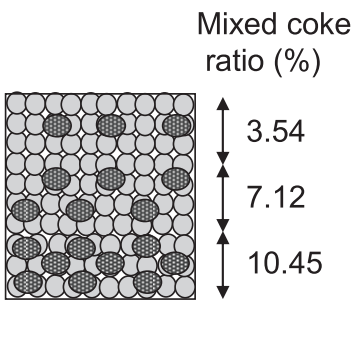

Case2

Fig. 2. Mixing conditions of coke in ore layer mixed with coke. 


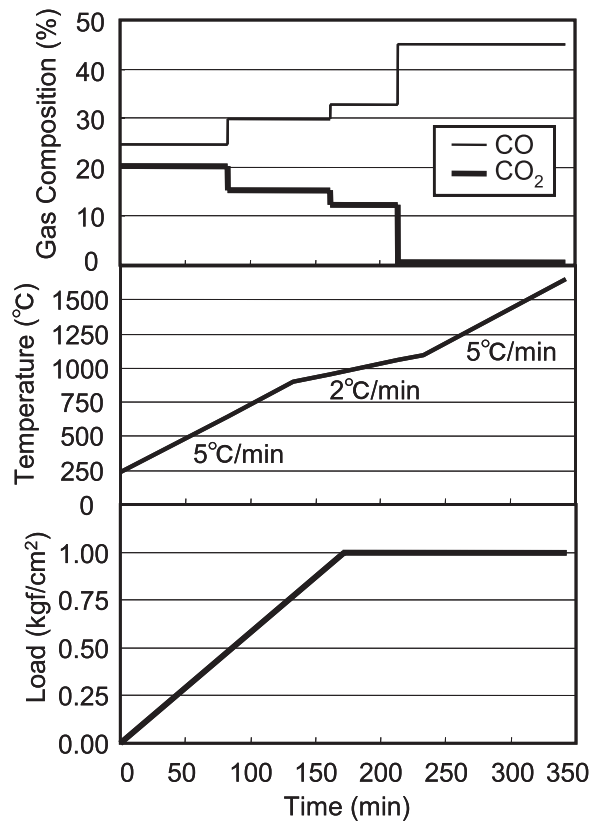

Fig. 3. Experimental conditions (gas composition, heating pattern and load).

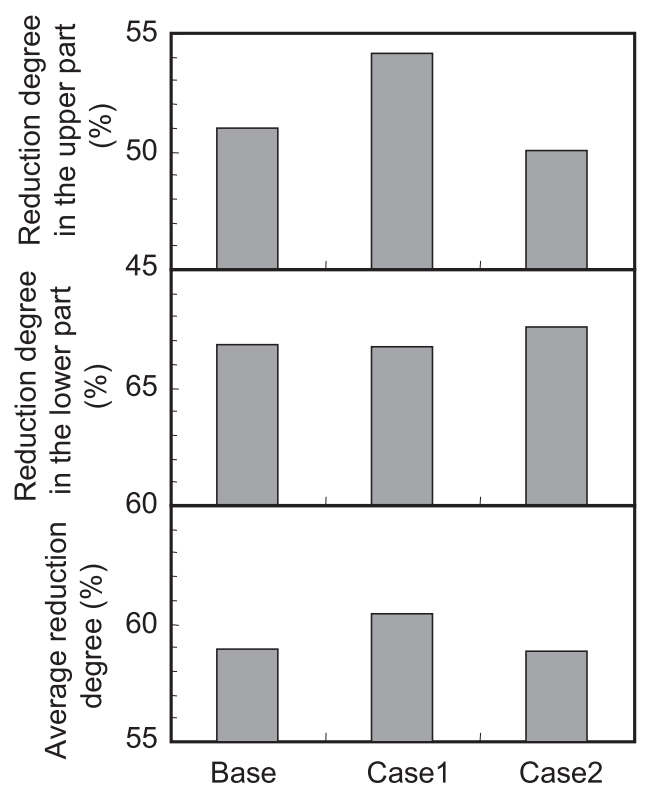

Fig. 4. Effect of mixed coke ratio distribution in ore layer mixed with coke on reduction degree.

In the lower part of the ore layer mixed with coke, in which the reduction degree was high, the reduction degree of Case 2 was high depending on the difference in the mixed coke ratio. In the upper part of the layer, in which the reduction degree was low, the reduction degree of Case 1 was high depending on the difference in the mixed coke ratio. As a result, in the case of the high mixed coke ratio in the upper part of the ore layer mixed with coke (Case 1), the average reduction degree of the ore layer mixed with coke was high. Accompanying the increase in the mixed coke ratio in the upper part of the ore layer mixed with coke, in which the reduction degree was low, the reduction degree in the upper part increased, and the average reduction degree of the layer also increased. It was thought that $\mathrm{CO}_{2}$ gas generated by the reduction reaction in the lower part of the ore layer mixed with coke ascended into the upper part of the layer and the reduction reaction and carbon gasification reaction in the upper part of the layer were accelerated more than the reactions in the lower part of the layer.

Therefore, in the case of the high mixed coke ratio, the average reduction degree of the ore layer mixed with coke increased as a result of the increase in the mixed coke ratio in the low reduction degree zone.

\section{Effect of Charging Method on Mixed Coke Ratio Distribution in Ore Layer Mixed with Coke}

\subsection{Experimental Procedure}

Next, a charging method for achieving a high mixed coke ratio in the upper part of the ore layer mixed with coke after charging the mixture of coke and ore burden materials in the blast furnace was investigated. As a general charging method, the ore batch which forms the ore layer mixed with coke was divided into two batches as materials for the upper part and lower part, and the ore batch for the lower part was set to a low mixed coke ratio, while the ore batch for the upper part was set to a high mixed coke ratio. These results in the formation of an ore layer mixed with coke in which the lower part has a low mixed coke ratio and the upper part has a high mixed coke ratio. However, when the number of the ore batch is increased, the charging speed per time must also be increased in order to maintain the production rate. Therefore, when the production rate is increased, the charge of materials may be late due to limitations related to the capacity of the facilities. Thus, the object of investigation in this study was a charging method for achieving a mixed coke ratio distribution in which the lower part has a low mixed coke ratio and the upper part has a high mixed coke ratio at the furnace top after charging in a scale model experiment without an increase in the number of the ore batch.

A schematic illustration of the experimental apparatus is shown in Fig. 5. The experimental apparatus is a $1 / 17.8$ scale model of Chiba No. 6 blast furnace, which has a bellless type charging system with three parallel top bunkers. To simulate the charging system of the actual blast furnace, the scale model consists of an ore bin, a coke bin, a surge hopper and belt conveyers. The Froude number, which is the ratio of inertia to gravity, was used for the charged material. ${ }^{15)}$ The Froude number in this experiment was set to the same value as that of the actual blast furnace, and the charging rate and rotation speed $(42.2 \mathrm{rpm})$ were decided based on the charging conditions under actual operating conditions. The particle size distributions of each material used in this experiment are shown in Fig. 6.

The charging weight and charging time of each batch are shown in Table 2. The coke rate was $400 \mathrm{~kg} / \mathrm{t}$. In this experiment, raw ore (red) as the ore of O1 batch, sinter (black) as the ore of $\mathrm{O} 2$ batch and colored sand (white) as small coke were used in order to distinguish the mixed coke in the ore layer in observation of the cross section. ${ }^{8)}$ Because the bulk density $\left(1740 \mathrm{~kg} / \mathrm{m}^{3}\right)$ of the ore was much smaller than the bulk density $\left(2010 \mathrm{~kg} / \mathrm{m}^{3}\right)$ of the sinter, the charging weight of O1 was controlled as same as the volume of sinter.

This experiment simulated the charging method used at Chiba No. 6 blast furnac. ${ }^{8)}$ At Chiba No. 6 blast furnace, 


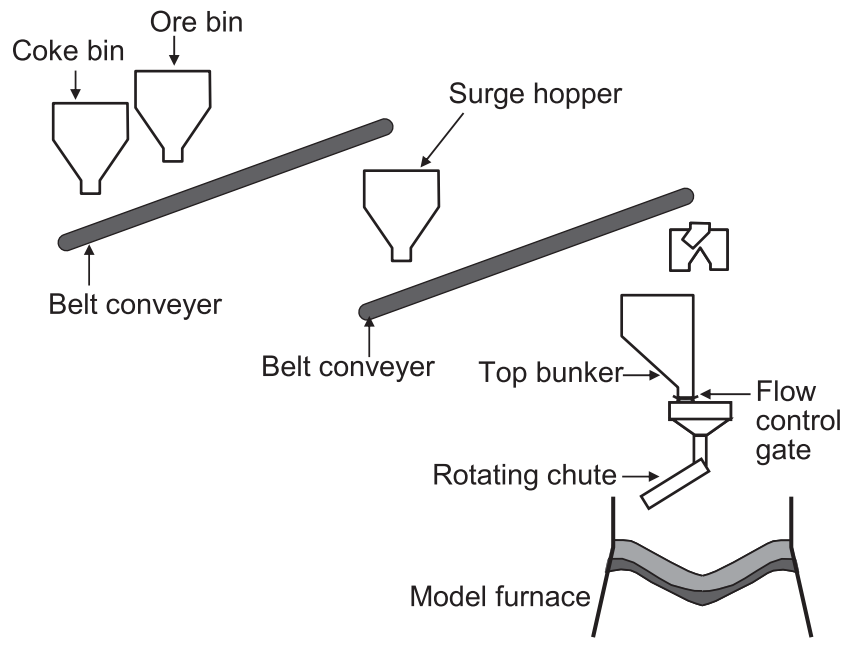

Fig. 5. Experimental apparatus for material charging.

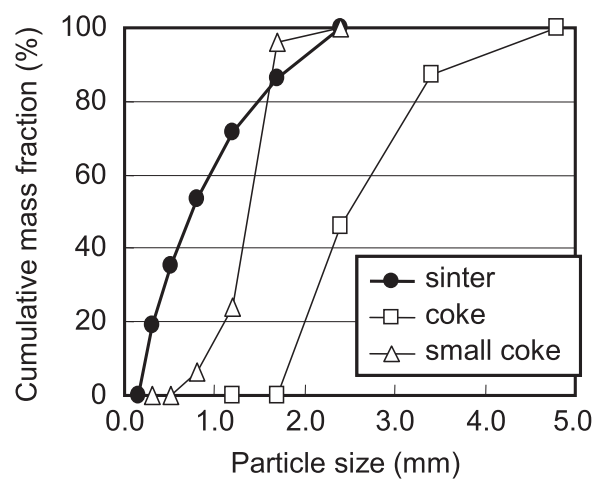

Fig. 6. Experimental conditions (particle size of sinter, coke and small coke).

Table 2. Comparison of charging weight and charging time between actual plant and experiment.

\begin{tabular}{|c|c|c|c|c|}
\hline & \multicolumn{2}{|c|}{ Actual Plant } & \multicolumn{2}{|c|}{ Experiment } \\
\hline & $\begin{array}{l}\text { Charging } \\
\text { weight (t) }\end{array}$ & $\begin{array}{l}\text { Charging } \\
\text { time (sec) }\end{array}$ & $\begin{array}{c}\text { Charging } \\
\text { weight (kg) }\end{array}$ & $\begin{array}{l}\text { Charging } \\
\text { time (sec) }\end{array}$ \\
\hline $\mathrm{C} 1$ & 28.4 & 120 & 5.03 & 28.4 \\
\hline $\mathrm{C} 2$ & 11.3 & 96 & 2.01 & 22.8 \\
\hline O1 & 107.7 & 48 & 16.54 & 11.4 \\
\hline $\begin{array}{c}\mathrm{O} 2+ \\
\text { Small coke }\end{array}$ & $82.3+8.1$ & 48 & $14.59+1.44$ & 11.4 \\
\hline
\end{tabular}

coke is charged in two batches $(\mathrm{C} 1, \mathrm{C} 2)$ and ore is charged in two batches $(\mathrm{O} 1, \mathrm{O} 2)$. The lump coke of the second coke batch $(\mathrm{C} 2)$ was mixed into the first ore batch $(\mathrm{O} 1)$, and the small coke was mixed into the second ore batch $(\mathrm{O} 2)$. The lump coke of $\mathrm{C} 2$ and the ore of $\mathrm{O} 1$ were mixed by simultaneously discharging the two materials from the respective top bunkers. The small coke was mixed with the ore on the belt conveyer. In this experiment, the discharge of the small coke and the ore were started simultaneously, and the discharge of the small coke was finished when one third of the ore weight was discharged.

A method for controlling the mixed coke ratio distribution in $\mathrm{O} 2$, which was mixed with small coke, was investigated. The mixed material discharged from each bin was charged to the top bunker. The shape of the burden stacked in the top

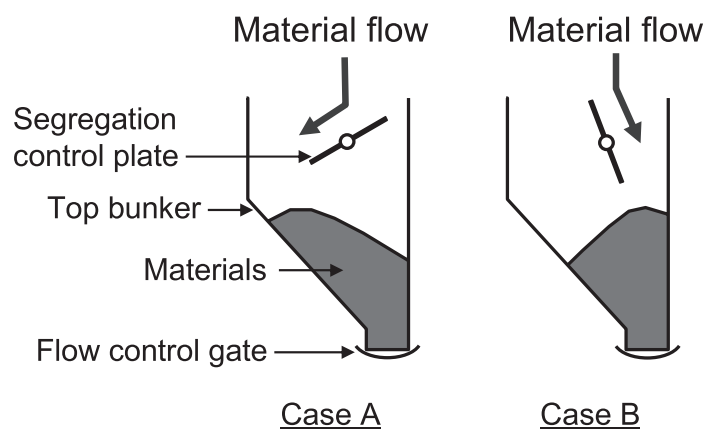

Fig. 7. Schematic illustrations of burden shape charged in top bunker.

bunker was changed by controlling the segregation control plate. ${ }^{16)}$ Schematic illustrations of the burden shape in the top bunker under each condition are shown in Fig. 7. Case A is the condition in which the mixed materials were stacked so that the top of the mixed materials was at the far side from the flow control gate. Case B is the condition in which the mixed materials were stacked so that the top of the mixed materials was at the side near the flow control gate.

In each case, the mixed materials discharged from the top bunker were collected in a series of boxes moving on the belt conveyer under the top bunker, and the change in the mixed coke ratio discharged from the top bunker was measured. The collected mixed materials were separated by gravity separation method using a sodium iodide solution. ${ }^{6}$

Next, to investigate the mixed coke ratio distribution in the top bunker, the mixed materials stacked in the top bunker were collected. The mixed materials stacked in the top bunker were collected by using a top bunker having an observation side (half of the bunker) made from an acrylic plate. After the mixed materials were charged in the halftop bunker, the space which was existed on the stacked materials was filled with urethane foam to fix the materials, and the half-top bunker was turned so that the acrylic plate was at the top. After the acrylic plate was removed, the mixed materials in all positions were collected by inserting cylinders $30 \mathrm{~mm}$ in diameter into the burden surface. The collected materials were separated by the same method as the sample collected under the top bunker, and mixed coke ratio was measured at all positions.

Next, the mixed coke ratio distribution in the ore layer mixed with coke at the furnace top after charging was investigated under each condition. In Case B, it is thought that the discharge behavior of the mixed coke ratio from the top bunker was different from that in Case A, therefore, it is thought that changes occur not only in the mixed coke ratio distribution in the upper part and lower part of the ore layer mixed with coke, but also in the radial distribution of the mixed coke ratio in the layer. At Chiba No. 6 blast furnace, reverse tilting charging ${ }^{2}$ is applied. In the case of a high mixed coke ratio in the final stage of discharge in Case B, the mixed coke ratio in the peripheral zone of the furnace top becomes significantly higher. Therefore, the charging method was changed in order to restrain this tendency in the mixed coke ratio distribution. In this experiment, the charging method (O2) of Case A was reverse tilting. About the charging method $(\mathrm{O} 2)$ of Case $\mathrm{B}$, in the initial stage of charging to the furnace top, the mixed material was 


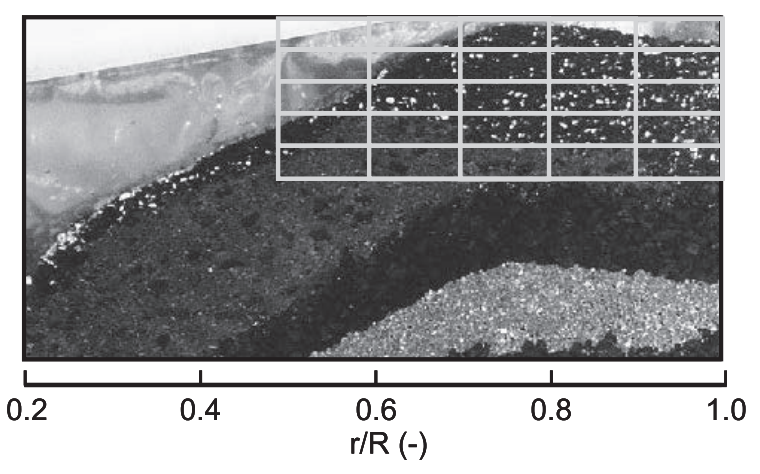

Fig. 8. Method of image analysis (mesh division).

charged from the middle area to the peripheral area. When the mixed materials were charged in the nearest area to the periphery in this charging, the charging of a half weight of this charged material was finished. Then, in the final stage of charging to the furnace top, the mixed material was charged from the peripheral area to the middle area. When the mixed materials were charged in the nearest area to the center in this charging, the charging of the residual charged material was finished (i.e., reverse and conventional tilting). The nearest area to the center and the nearest area to the periphery in the charging $(\mathrm{O} 2)$ of Case A and Case B were same. About C1, C2 and O1, the charging method was same.

After charging to the furnace top, a low viscosity liquid resin was poured from the surface of the burden, and a sample was cut off after the resin had solidified in order to observe the cross section of the burden. Image analysis was performed to quantify the mixed coke ratio distribution in the ore layer mixed with coke. ${ }^{8)}$ The analysis area was divided into five meshes in the radial direction and five meshes in the height direction, and the mixed coke ratio was measured in the each mesh, as shown in Fig. 8.

\subsection{Experimental Results and Discussion}

3.2.1. Change in Mixed Coke Ratio Discharged from Top Bunker

Figure 9 shows the change in the mixed coke ratio discharged from the top bunker. By controlling the burden shape stacked in the top bunker, the change in the mixed coke ratio discharged from the top bunker was controlled. In Case $\mathrm{A}$, the difference between the maximum and the minimum value of the mixed coke ratio was smaller than that in Case B, and the mixed coke ratio discharged from the top bunker in the final stage became high in Case B.

Figure 10 shows the discharge pattern from the top bunker of the scale model. This discharge pattern was measured by the condition of the flat material profile. This result was obtained by a tracer experiment using alumina balls $3 \mathrm{~mm}$ in diameter. The alumina balls were set at intervals of 40 $\mathrm{mm}$ in the materials charged in the top bunker. Numbers were assigned and written on the alumina balls at each position. After collecting the alumina balls discharged from the top bunker, the relationship between the positions of the alumina balls set in the top bunker and the discharge time of the balls was determined. This result shows that the material stacked on the side near the flow control gate was discharged in the initial stage and the material stacked on the far side from the flow control gate was discharged in the

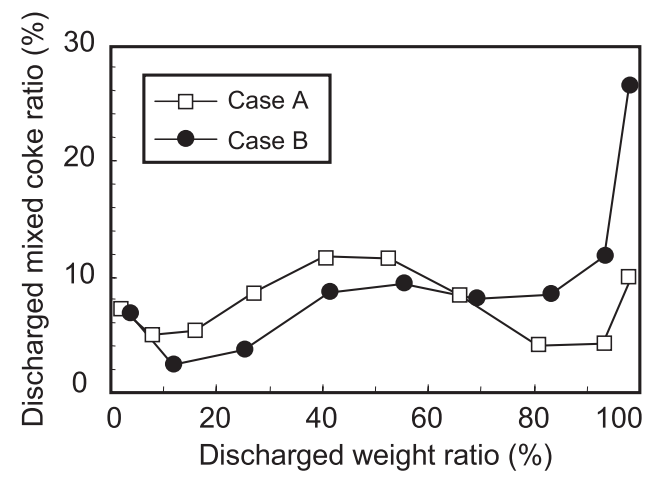

Fig. 9. Change in mixed coke ratio discharged from top bunker.

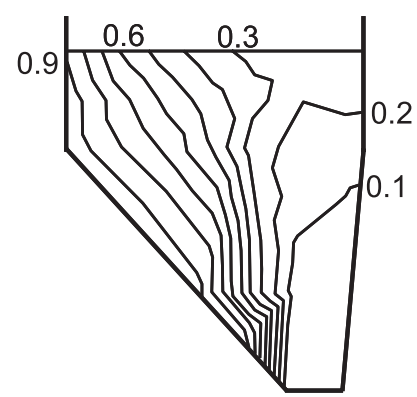

Fig. 10. Dimensionless discharge time distribution in top bunker.

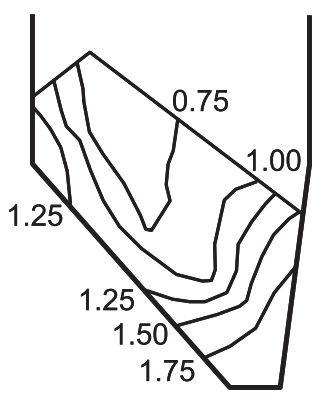

Case A

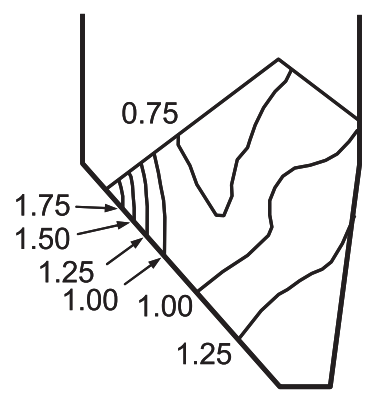

Case B
Fig. 11. Comparison of dimensionless mixed coke ratio distribution in top bunker.

final stage, qualitatively.

Figure 11 shows the non-dimensional mixed coke ratio distribution in the top bunker. In charging mixed materials on the side near the flow control gate in Case B, the small coke was stacked on the far side from the flow control gate by a segregation phenomenon because the particle size of the small coke was larger than that of the sinter and the density of the small coke was smaller than that of the sinter. ${ }^{17,18)}$ The material stacked on the far side from the flow control gate was discharged from the top bunker in the final stage, as shown in Fig. 10. Therefore, the mixed coke ratio discharged from the top bunker became high in the final stage in Case B.

\subsubsection{Mixed Coke Ratio Distribution at Furnace Top after Charging}

Figure 12 shows a comparison of the observation results of the cross sections after charging. The sinter and mixed small coke were stacked in the upper part of the ore layer mixed with coke in the peripheral area. A small amount of 
the mixed small coke was stacked in the central part by the segregation. In Case A, the small coke charged with the sinter was stacked uniformly in the upper part and the lower part of the ore layer mixed with coke, but in Case B, much of the small coke charged with the sinter was stacked in the upper part of the layer.

Figure 13 shows the mixed coke ratio distribution in the height direction in the cross sections of the ore layer mixed with coke obtained by image analysis. ${ }^{8)}$ In Case A, the mixed coke ratio in the upper part and lower part of the ore layer mixed with coke was relatively uniform. However, in Case B, the mixed coke ratio in the upper part of the ore layer mixed with coke was higher than the mixed coke ratio in the lower part. In the initial stage of charging, the materials charged from the top bunker were stacked in the lower part of the ore layer mixed with coke, whereas, in the final stage of charging, the materials charged from the top bunker were stacked in the upper part. Therefore, in Case B, the mixed coke ratio in the lower part of the ore layer mixed with coke was low, and the mixed coke ratio in the upper part of the ore layer mixed with coke was high.

Figure 14 shows the radial mixed coke ratio distribution in the ore layer mixed with coke. Although the changes in the mixed coke ratio discharged from the top bunker were

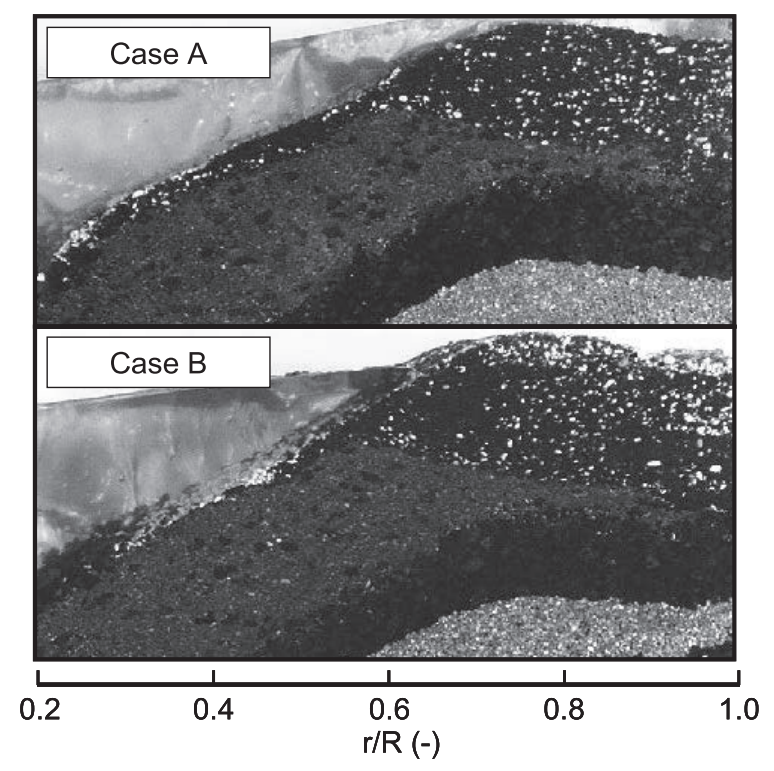

Fig. 12. Comparison of cross-sections after charging.

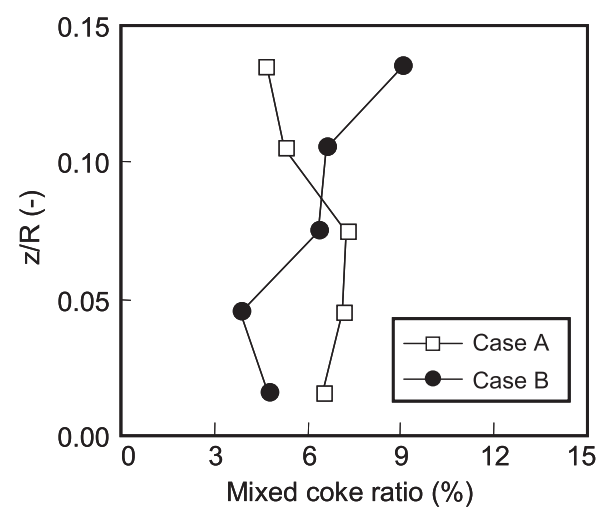

Fig. 13. Mixed coke ratio distribution in height direction in ore layer mixed with coke. different in Case A and Case B, the radial mixed coke distributions in Case A and Case B showed similar results.

In case of reverse and conventional tilting, the mixed coke in the initial stage and the final stage was charged in same area. Therefore, in Case B, materials with a low mixed coke ratio and materials with a high mixed coke ratio were charged in the same middle area, and the mixed coke ratio in the middle area was averaged.

\section{Operating Test for Examination of Change in Mixed Coke Ratio Distribution in Ore Layer Mixed with Coke}

To estimate the effect of mixing coke at a high ratio in the upper part of the ore layer mixed with coke, an operating test was carried out at Chiba No. 6 blast furnace. At Chiba No. 6 blast furnace, coke is charged in two batches $(\mathrm{C} 1, \mathrm{C} 2)$ and ore is charged in two batches (O1, O2), and $120 \mathrm{~kg} / \mathrm{t}$ coke mixed ratio operation is conducted. ${ }^{8)}$ In $\mathrm{O} 2$ of period A, the mixed materials were stacked as the top of the mixed materials at the far side from the flow control gate of the top bunker, as shown in Case A of Fig. 7. Therefore, it is predicted that the mixed coke ratios in the lower part and upper part of the ore layer mixed with coke are the mixed coke ratio shown in Fig. 13 (Case A) obtained by the laboratory experiment. In contrast, in $\mathrm{O} 2$ of period $\mathrm{B}$, the mixed materials were stacked as the top of the mixed materials at the side near the flow control gate of the top bunker, as shown in Case B of Fig. 7. Therefore, in Case B, it is predicted that the mixed coke ratio is low in the lower part and high in the upper part of the ore layer mixed with coke shown in Fig. 13 (Case B). The amount of mixed coke was constant in period $\mathrm{A}$ and period $\mathrm{B}$, and reverse and conventional tilting was selected in $\mathrm{O} 2$ of both periods.

Table 3 shows a comparison of the operational data for period $\mathrm{A}$ and period $\mathrm{B}$. These data are average data of the daily data for each two weeks. Gas utilization in period B was higher than that in period A. The hot metal temperature was kept basically constant during both periods, and gas permeability was stable during the both periods.

Figure 15 shows the typical gas utilization distribution obtained by the shaft gas sampler during period $\mathrm{A}$ and period $\mathrm{B}$. In period $\mathrm{B}$, gas utilization increased in the blast furnace peripheral area $(\mathrm{r} / \mathrm{R}=0.7-1.0)$. This peripheral

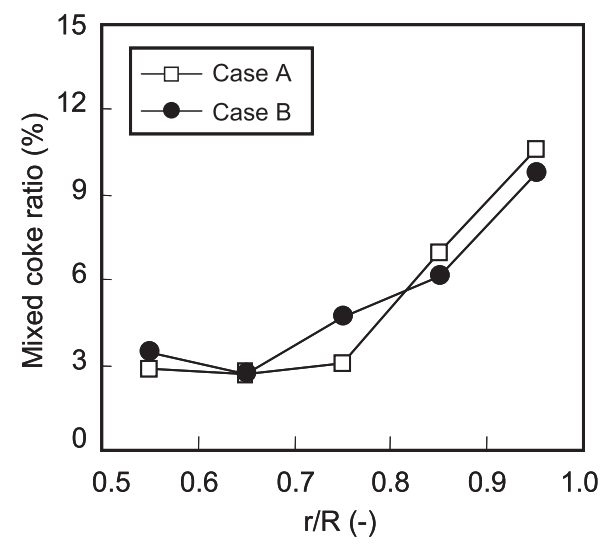

Fig. 14. Radial distribution of mixed coke ratio in ore layer mixed with coke. 
Table 3. Comparison of operational data during period A and period B.

\begin{tabular}{lccc}
\hline & & Period A & Period B \\
\hline Productivity & $\mathrm{t} / \mathrm{d} / \mathrm{m}^{3}$ & 2.26 & 2.28 \\
RAR & $\mathrm{kg} / \mathrm{t}$ & 488.0 & 487.2 \\
$\mathrm{CR}$ & $\mathrm{kg} / \mathrm{t}$ & 377.3 & 373.6 \\
Permeability Index & - & 0.964 & 0.969 \\
$\eta$ co & $\%$ & 49.5 & 50.0 \\
Shaft efficiency & - & 0.898 & 0.905 \\
Hot metal temp. & ${ }^{\circ} \mathrm{C}$ & 1504 & 1502 \\
Coke DI & $\%$ & 83.6 & 83.1 \\
Sinter RDI & $\%$ & 32.1 & 32.7 \\
Sinter RI & $\%$ & 62.5 & 62.7 \\
\hline
\end{tabular}

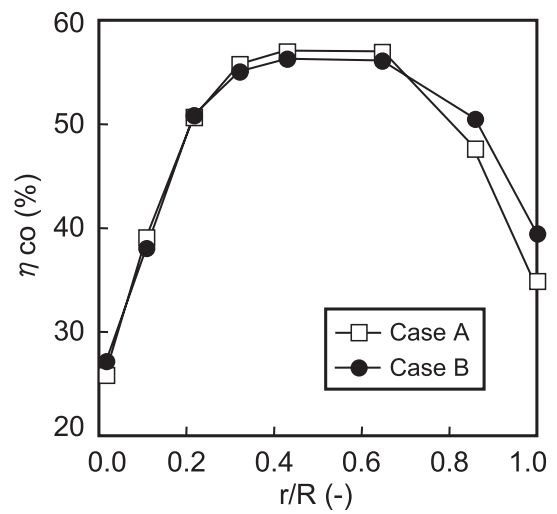

Fig. 15. Comparison of gas utilization obtained by shaft gas sampler during period $\mathrm{A}$ and period $\mathrm{B}$.

area is the area where $\mathrm{O} 2$ was charged, as shown in the result of the scale model experiment in Fig. 12. Therefore, the increase in gas utilization was estimated to be a result of acceleration of the reduction rate due to the increase in the mixed coke ratio in the upper part of ore layer mixed with coke, as shown in the results of the reduction test in Fig. 4. Thus, although further investigation may be necessary in order to determine the most suitable mixed coke ratio distribution in the ore layer mixed with coke, mixing coke at a high ratio in the upper part of the ore layer mixed with coke is expected to be an effective measure for increasing gas utilization in the blast furnace.

\section{Conclusions}

A method for accelerating the ore reduction rate in the blast furnace by controlling the mixed coke ratio distribution in the ore layer mixed with coke was studied with the aim of achieving low RAR operation. The effect of the mixed coke ratio distribution on the ore reduction rate under the condition of a high mixed coke ratio was investigated by a reduction test under load. The mixed coke ratio at the furnace top after charging was investigated by a scale model experiment. An operating test was also carried out at an actual blast furnace. The following conclusions were obtained.

(1) The average reduction degree of the ore layer mixed with coke increased as a result of an increase in the mixed coke ratio in the upper part of the ore layer mixed with coke, even in the case of a high mixed coke ratio. The reduction degree of the ore in the upper part of the ore layer mixed with coke was lower than that of the ore in the lower part of the layer, even with a high mixed coke ratio. Thus, the reduction rate of the ore in the upper part of the layer mixed with coke increased as a result of the increase in the mixed coke ratio in the upper part of the layer, and in this case, the average reduction degree of the ore in the layer also increased.

(2) When mixed materials were charged at the side near the flow control gate of the top bunker, the mixed coke ratio discharged from the top bunker increased in the final stage of discharge. Therefore, in charging at the furnace top, the mixed coke ratio stacked in the lower part of the ore layer mixed with coke was low, and the mixed coke ratio stacked in the upper part of the ore layer mixed with coke was high. With reverse and conventional tilting, the radial mixed coke ratio distribution in the case of a high mixed coke ratio in the final stage of discharge was similar to the radial mixed coke ratio distribution in the case of a uniform mixed coke ratio from the start of discharge to the end of discharge.

(3) An operating test in which a large amount of coke was charged in the upper part of the ore layer mixed with coke was carried out at Chiba No. 6 blast furnace. Gas utilization in the blast furnace peripheral area increased, and the average gas utilization at the furnace top also increased. The hot metal temperature and gas permeability were stable during the test.

\section{REFERENCES}

1) T. Ariyama and M. Sato: ISIJ Int., 46 (2006), 1736.

2) T. Sato, T. Nouchi, K. Takeda and H. Kamano: Tetsu-to-Hagané, 86 (2000), 648.

3) T. Sato, M. Sato, K. Takeda and T. Ariyama: Tetsu-to-Hagané, 92 (2006), 1006.

4) H. Kokubu, K. Sato, Y. Konishi, S. Taguchi, S. Sakurai, K. Okumura and K. Ichifuji: Tetsu-to-Hagané, 70 (1984), S50.

5) K. Okuda, K. Yamaguchi, N. Ishioka, K. Furukawa and H. Endo: Tetsu-to-Hagané, 70 (1984), S102.

6) S. Watakabe, K. Takeda, H. Nishimura, S. Goto, N. Nishimura, T. Uchida and M. Kiguchi: ISIJ Int., 46 (2006), 513.

7) M. Sawayama, K. Miyagawa, Y. Matsui, S. Tagawa and S. Kitano: CAMP-ISIJ, 20 (2007), 77.

8) A. Murao, Y. Kashihara, S. Watakabe and M. Sato: ISIJ Int., 51 (2011), 1360.

9) Y. Kashihara, A. Murao, Y. Sawa, M. Sato, S. Hirooka and M. Kuwabara: CAMP-ISIJ, 23 (2010), 1013, CD-ROM.

10) A. Murao, Y. Kashihara, S. Watakabe, M. Sato and N. Ogawa: CAMP-ISIJ, 23 (2010), 1014, CD-ROM.

11) T. Orimoto and M. Naito: CAMP-ISIJ, 13 (2000), 894

12) S. Matsuzaki, T. Orimoto, S. Nomura, K. Higuchi, K. Kunitomo and M. Naito: CAMP-ISIJ, 17 (2004), 10.

13) N. Uchida, M. Sawayama, K. Miyagawa and K. Nomura: CAMPISIJ, 24 (2011), 109, CD-ROM.

14) H. Kokubu, A Sasaki, S. Taguchi and N. Tsuchiya: Tetsu-to-Hagané, 68 (1982), 2338

15) S. Miyagawa, K. Takeda, S. Taguchi, T. Morimoto, M. Fujita and H. Fujimori: Kawasaki Steel Giho, 23 (1991), 130.

16) T. Sawada, T. Uetani, S. Taniyoshi, M. Miyagawa, H. Sugawara and M. Yamazaki: Tetsu-to-Hagané, 78 (1992), 1337.

17) K. Sunahara, C. Kamijo and T. Inada: Ironmaking Conf. Proc., AIST, Warrendale, PA, (1999), 3.

18) S. Matsuzaki and Y. Taguchi: Tetsu-to-Hagané, 88 (2002), 823. 